\title{
Heavy Metals Contamination Assessment of Water and Soils in and Around Barapukuria Coal Mine Area, Bangladesh
}

\author{
Md. Hafijur Rahaman Khan ${ }^{1,2,3 \text {, * Ashraf Ali Seddique }{ }^{4} \text {, Ananna Rahman }{ }^{1,2,3} \text {, Yuta Shimizu }}$ \\ ${ }^{1}$ Key Laboratory of Marginal Sea Geology, South China Sea Institute of Oceanology, Chinese Academy of Sciences, Guangzhou, China \\ ${ }^{2}$ University of Chinese Academy of Sciences, Beijing, China \\ ${ }^{3}$ Department of Petroleum and Mining Engineering, Jessore University of Science and Technology, Jessore, Bangladesh \\ ${ }^{4}$ Department of Environmental Science and Engineering, Jatiya Kabi Kazi Nazrul Islam University, Mymensingh, Bangladesh \\ ${ }^{5}$ Western Region Agricultural Research Center, National Agriculture and Food Research Organization, Japan
}

Email address:

mdhrsumon14@gmail.com (Md. H. R. Khan), aseddique@yahoo.com (A. A. Seddique), hrananna02@gmail.com (A. Rahman)

${ }^{*}$ Corresponding author

\section{To cite this article:}

Md. Hafijur Rahaman Khan, Ashraf Ali Seddique, Ananna Rahman, Yuta Shimizu. Heavy Metals Contamination Assessment of Water and Soils in and Around Barapukuria Coal Mine Area, Bangladesh. American Journal of Environmental Protection.

Vol. 6, No. 4, 2017, pp. 80-86. doi: 10.11648/j.ajep.20170604.11

Received: May 12, 2017; Accepted: June 21, 2017; Published: July 18, 2017

\begin{abstract}
In order to evaluate the heavy metals contamination of groundwater in Barapukuria Coal Mine (BCM) area and its vicinity, nine groundwater samples from different location, two waste water either treated and/or untreated that were used to irrigate in and around the coal mine areas, three surficial soil samples $(\sim 20 \mathrm{~cm}$ depth $)$ and a coal dust sample were collected during March, 2015. The samples were analyzed by inductively coupled plasma mass spectrometry (ICP-MS). Each sample was analyzed for $\mathrm{As}, \mathrm{Mn}, \mathrm{Fe}^{\text {total }}, \mathrm{Cu}, \mathrm{Pb}, \mathrm{Zn}, \mathrm{Mo}, \mathrm{Ni}, \mathrm{Co}, \mathrm{Cr}, \mathrm{Cd}$ and $\mathrm{Hg}$. It was found that $\mathrm{As}, \mathrm{Cu}, \mathrm{Pb}, \mathrm{Zn}, \mathrm{Mo}, \mathrm{Co}, \mathrm{Cr}, \mathrm{Cd}$ and $\mathrm{Hg}$ did not exhibit significant elevated levels, but concentration of $\mathrm{Mn}, \mathrm{Fe}^{\text {total }}$ and $\mathrm{Ni}$ ranging from 0.15 to $3.85 \mathrm{mg} / \mathrm{L}, 0$ to $1.88 \mathrm{mg} / \mathrm{L}$ and 0.01 to $0.09 \mathrm{mg} / \mathrm{L}$ respectively both in groundwater and mine waste water samples exceeded the World Health Organization (WHO, 2004) drinking water guideline values of $0.4 \mathrm{mg} / \mathrm{L}$ of $\mathrm{Mn}, 0.3 \mathrm{mg} / \mathrm{L}$ of $\mathrm{Fe}$ and of $0.02 \mathrm{mg} / \mathrm{L}$ of Ni. Similarly the mean heavy metal concentrations in soils were below the Bangladesh standards for all heavy metals but the maximum values of Co $(137.25$ to $245.24 \mathrm{mg} / \mathrm{kg}), \mathrm{Cr}(139.02$ to $243.38 \mathrm{mg} / \mathrm{kg})$ and $\mathrm{Hg}$ (0 to $24.28 \mathrm{mg} / \mathrm{kg}$ ) also exceeded the maximum acceptable limit of Food and Agricultural Organization (FAO, 1992) (Co of $50 \mathrm{mg} / \mathrm{kg}, \mathrm{Cr}$ of $100 \mathrm{mg} / \mathrm{kg}$ ) and Environment Agency $(E A, 2009)(\mathrm{Hg}$ of $1 \mathrm{mg} / \mathrm{kg}$ ) guideline standard. However, the coal dust was not above the guideline recommended limit for any elements. Therefore, this study reveals that the use of treated and/or untreated coal mine waste water for irrigation has increased the risk of heavy metals contamination in groundwater and causing potential health hazards in the long time term.
\end{abstract}

Keywords: Barapukuria, Groundwater, Heavy Metals, Contamination, Coal Mine

\section{Introduction}

Water is very important natural resource, widely used throughout the world for domestic, industrial, commercial or agricultural purposes and entering into the environment in various sources $[1,3]$. However, the problem of water quality is more severe in the areas where mining and mineral processes' industries are present. Especially in mining processes, several classes of wastes are produced which may cause various types of pollution and then ultimately contamination occurs $[1,23]$. So, it is of great importance to evaluate the ground water in every developing country like Bangladesh where $95 \%$ of the portable water supply comes from groundwater both in rural and urban areas and $70 \%$ of irrigation water also comes from groundwater sources [3, 24]. 
The coal-mining operations either by underground or open-cut mining is the most recognizable and demonstrable environmental problem since it modifies or by altering the physical, chemical and biological parameters of the environment surround to the mining area and it has farreaching influence on human being civilization and ecological unit $[1,2]$. The mine drainage contains high concentrations of metals and metalloids which elevate minerals contents in ground water and soil might be one of major pollution sources. The release of mining waste to the environment can be caused in intense destruction of ecosystems, which, in some cases, may not be fully restored or rehabilitated [2]. Indeed, coal mine drainage ranges widely in composition from acid to alkali, typically with high concentration of heavy metals like, $\mathrm{Fe}, \mathrm{Mn}, \mathrm{Cu}, \mathrm{Ni}$, which can fatally degrade the aquatic habitat and the quality of water supplies because of toxicity, corrosion, encrustation and other effects from dissolved constituents [1]. Though some heavy metals (like $\mathrm{Fe}, \mathrm{Cu}, \mathrm{Zn}, \mathrm{Ni}$ ) and other trace elements are very essential for proper functioning of biological systems for both animals and plants, their deficiency or excess could cause to a number of disorders. So, food chain contamination by heavy metals has become a pressing issue in recent years because of their potential accumulation in bio-systems through contaminated water, soil and air [15].

The population density of the study area is about 685 people per sq.km who are mostly depend on the ground water in various needs like drinking, cooking, irrigation. About $80 \%$ of the diseases in the world population and more than one-third of the deaths in the developing countries are due to contamination of water $[5,6]$. So, the local people might be affected by heavy metals contamination as recent studies have found that groundwater in many parts of the world is contaminated with heavy metals from coal mining [4]. Previous studies were concerned only about the impacts of coal mining and land use changes on groundwater pollution in the Barapukuria Coal Mine (BCM) and its surrounding areas and suggested for environmental monitoring and understanding pollution pathways in the environment $[1,24]$.

As the groundwater is the major source of water supply for drinking, cooking and irrigation purposes in the study area, the knowledge on hydro-chemical and geochemical characteristics is more important to assess the ground and surface water quality for understanding its suitability for different purposes. Therefore, understanding the characteristics of mine drainage as well as water bodies is important. However, no systematic investigation of heavy metals concentration to groundwater has been attempted in this study area so far. The present study was carried out to evaluate heavy metals concentration of soil and water being used for drinking, cooking or irrigation as well as their relationship with the groundwater chemistry.

\section{Hydrogeology of Barapukuria Coal Basin}

Based on hydrogeological setting of the BCM, mine belongs to a much more complex hydrogeological condition than other areas in Bangladesh [1]. In fact, the principal constraints on the design of the BCM relate to the great thickness $(\sim 36 \mathrm{~m})$ of seam, the presence of massive Gondwana sandstones and unconsolidated Dupi Tila formation [7]. The lower formation represents a major aquifer over the whole mine area with thousands of sq. $\mathrm{km}$. of aerial extension which is at least $100 \mathrm{~m}$ in thickness reaching $185 \mathrm{~m}$ in the southern part of the mine area and extends from beneath a shallow covering of Barind clay residuum to its geologically unconformable contact with the groundwater measures [1]. The Dupitila formation and Gondwana sandstone, that is known to be hydraulic continuity with the coal seam VI, North Slope of the Platform, Platform Flank Zone represents a major potential hazard to the mine from water inflow $[1,25,26]$. BCM is an independent Gondwana coal-bearing basin, which is controlled by half-fault Graben and unconformably laid on the denuded Archean Basement Complex $[1,26]$. Based on brilling data, the strata can be divided into four units such as Basement complex, Gondwana group, Dupi Tila Formation and Barind Residuum Clay and their Lithology [25, 26], average thickness and hydrology have been shown in Table 1 .

Table 1. Hydrostratigraphic succession of the Barapukuria Coal Basin [8, 9].

\begin{tabular}{|c|c|c|c|c|}
\hline Age & Group/Formation & Lithology & $\begin{array}{l}\text { Average } \\
\text { Thickness (m) }\end{array}$ & Hydrology \\
\hline Holocene & Alluvium & Sand, silt, clay & 2 & - \\
\hline Pleistocene & Barind Clay Residuum & Clay and sandy clay & 10 & Aquiclude \\
\hline \multirow{2}{*}{ Pliocene } & Upper Dupi Tila & Sandstone, pebbly sandstone and clay/mudstone & 104 & Unconfined Aquifer \\
\hline & Lower Dupi Tila & Sandstone, claystone and mudstone with silica and white clay. & 80 & Aquiclude \\
\hline Permian & Gondwana & Feldspathic sandstone, carbonaceous sandstone, shale, coal beds. & 156 & Aquifer \\
\hline Precambrian & Basement complex & Diorite, granodiorite, quartzdiorite, granite and gneiss & 84 & Aquiclude \\
\hline
\end{tabular}

\section{Materials and Methods}

The study area is located in the Parbatipur Upazila, Dinajpur district, the north-western part of Bangladesh. Geographically, the study area is lies between the longitudes $88^{\circ} 56^{\prime} 31^{\prime \prime E}$ to $88^{\circ} 58^{\prime} 05^{\prime \prime E}$ and the latitude $25^{\circ} 32^{\prime} 17^{\prime \prime} \mathrm{N}$ to $25^{\circ} 33^{\prime} 51^{\prime \prime} \mathrm{N}$, respectively (Figure 1). The choice of the sampling points considered location, accessibility, proximity to residential areas and the adjacent outside area of the coal mine. In this study, (i) nine groundwater samples in different depth (70 220ft.) were chosen randomly in and around the 
coal mine areas, (ii) two coal mine waste water samples either treated and/or untreated among them one was drained by the coal mine and the other one was irrigated and/or drained by Barapukuria Coal Power Plant (BCPP), (iii) three surficial soils (up to $20 \mathrm{~cm}$ depth) near the drainage outlet of BCM and BCPP in the paddy field and (iv) a coal dust sample sieved from drainage water of BCM were collected during March, 2015. The collected water samples were filtered (Whatman no. 42) and preserved with $6 \mathrm{~N}$ of nitric acid $\left(\mathrm{HNO}_{3}\right)$ for further analysis [10] and solid (Soil and coal dust) samples were digested by EPA (3050B) Method.
Each sample was analyzed for $\mathrm{Fe}^{\text {total }}, \mathrm{Cu}, \mathrm{Zn}, \mathrm{Mo}, \mathrm{Ni}, \mathrm{Co}$, $\mathrm{Cr}, \mathrm{Mn}, \mathrm{Pb}, \mathrm{Cd}, \mathrm{Hg}$ and As using Induced Coupled Plasma Mass Spectrophotometer (ICP-MS) to evaluate their concentration levels at National Agriculture and Food Research Organization, Japan. The results obtained were compared with the World Health Organization (WHO, 2004) [18], Food and Agricultural Organization (FAO, 1992) [11], Environment Agency (EA, 2009) [12] and also Bangladesh (2009) $[13,27]$ guideline standard for the specified maximum contaminant level of heavy metals.

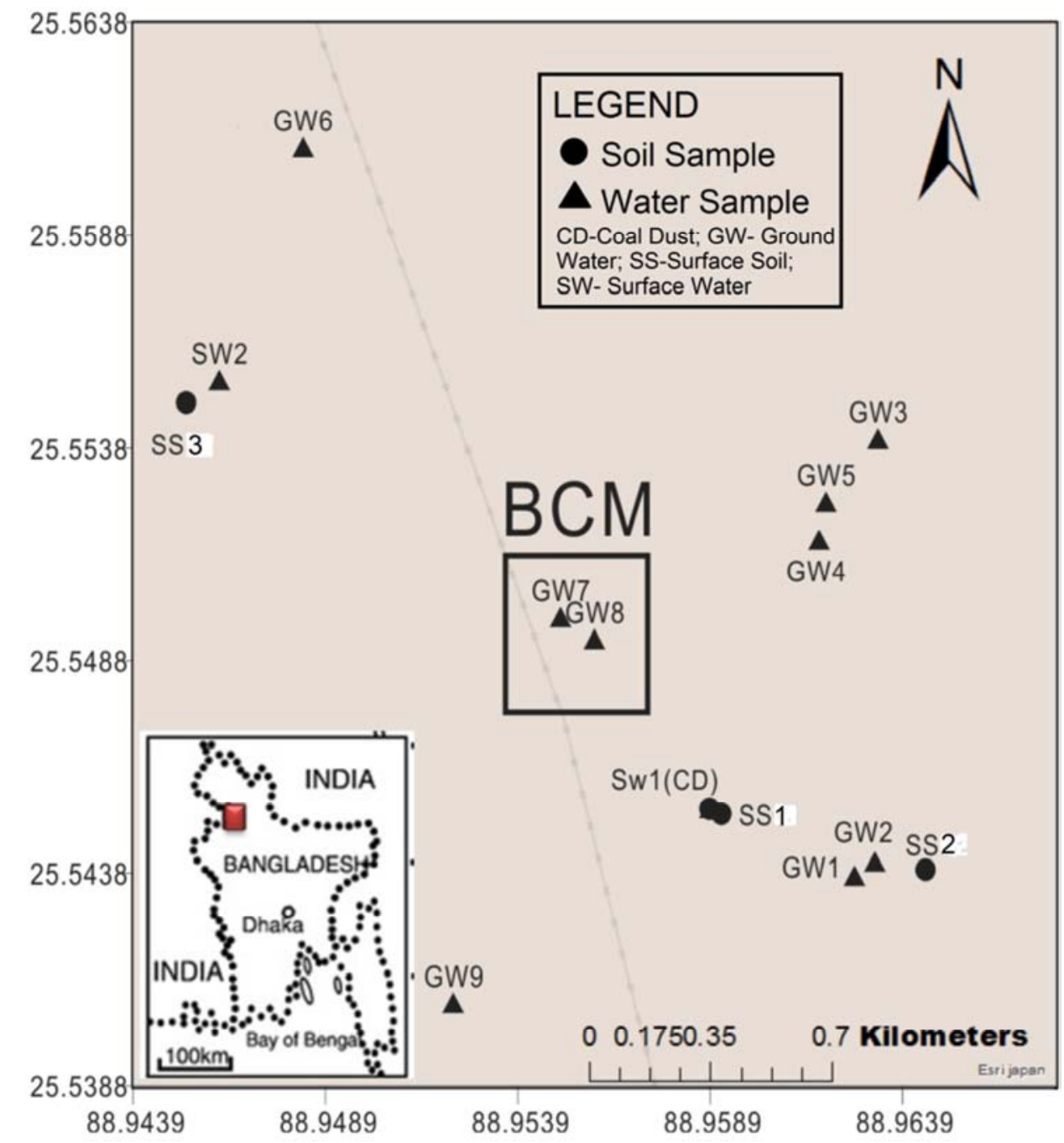

Figure 1. Location map of the study area showing sampling stations in and around Barapukuria Coal Mine (BCM).

\section{Results and Discussions}

The concentration level of heavy metals obtained by analysis in water, coal dust and soil samples are mentioned in Table 2 and Table 3. Metal concentrations of water are measured in $\mathrm{mg} / \mathrm{L}$, but the coal dust and soils in $\mathrm{mg} / \mathrm{kg}$ at dry weight. The concentrations of heavy metals in the water, soil and coal dust samples are shown in Figure 2 with their individual standards using the maximum allowable limit of World Health Organization (WHO-2004) and maximum guideline for Bangladesh (2009) for water (Table 2), FAO and EA permissible limit for soil (Table 3). A totals of 12 metals (Fe, $\mathrm{Cu}, \mathrm{Zn}, \mathrm{Mo}, \mathrm{Ni}, \mathrm{Co}, \mathrm{Cr}, \mathrm{Mn}, \mathrm{Pb}, \mathrm{Cd}, \mathrm{Hg}$ and $\mathrm{As}$ ) were analyzed for which are discussed below.

\subsection{Heavy Metals in Water}

Results showed that $\mathrm{As}, \mathrm{Cu}, \mathrm{Pb}, \mathrm{Zn}, \mathrm{Mo}, \mathrm{Co}, \mathrm{Cr}, \mathrm{Cd}$ and $\mathrm{Hg}$ did not exhibit significant elevated levels (Table 2), but concentration of $\mathrm{Mn}, \mathrm{Fe}^{\text {total }}$ and $\mathrm{Ni}$ ranging from 0.15 to $3.85 \mathrm{mg} / \mathrm{L}, 0$ to $1.88 \mathrm{mg} / \mathrm{L}$ and 0.01 to $0.09 \mathrm{mg} / \mathrm{L}$ respectively both in groundwater and mine waste water exceeded the World Health Organization (WHO, 2004) drinking water 
guideline values of $0.4 \mathrm{mg} / \mathrm{L}$ of $\mathrm{Mn}, 0.3 \mathrm{mg} / \mathrm{L}$ of $\mathrm{Fe}$ and of $0.02 \mathrm{mg} / \mathrm{L}$ of $\mathrm{Ni}$ (Table 2). Heavy metals (i.e., $\mathrm{Mn}, \mathrm{Fe}^{\text {total }}, \mathrm{Ni}$ ) found in drinking water represents a variety of health concerns and demonstrates adverse health effect at higher doses [14].

Table 2. Concentration $(\mathrm{mg} / \mathrm{L})$ of heavy metals measured in water and their guideline values.

\begin{tabular}{|c|c|c|c|c|c|c|c|c|c|c|c|c|}
\hline Sample ID & $\mathrm{Fe}$ & $\mathbf{C u}$ & Zn & Mo & $\mathbf{N i}$ & Co & $\mathrm{Cr}$ & Mn & $\mathbf{P b}$ & Cd & Hg & As \\
\hline SW1 & 0.067 & 0.004 & 0.007 & UDL & 0.087 & 0.036 & UDL & 1.14 & UDL & UDL & UDL & UDL \\
\hline SW2 & UDL & UDL & UDL & UDL & 0.047 & UDL & UDL & 0.961 & UDL & UDL & UDL & UDL \\
\hline GW1 & 1.84 & 0.01 & UDL & UDL & 0.05 & 0.04 & UDL & 2.65 & UDL & UDL & UDL & UDL \\
\hline GW2 & 1.88 & UDL & UDL & UDL & 0.03 & 0.10 & UDL & 3.85 & UDL & UDL & UDL & UDL \\
\hline GW3 & UDL & UDL & UDL & UDL & 0.01 & 0.01 & UDL & 0.56 & UDL & UDL & UDL & UDL \\
\hline GW5 & UDL & 0.01 & UDL & UDL & UDL & UDL & UDL & 0.17 & UDL & UDL & UDL & 0.03 \\
\hline GW6 & 0.05 & 0.01 & UDL & UDL & UDL & UDL & UDL & 0.15 & UDL & UDL & UDL & UDL \\
\hline GW7 & UDL & 0.00 & 0.17 & UDL & UDL & UDL & UDL & 0.58 & UDL & UDL & 0.09 & UDL \\
\hline GW8 & 0.59 & 0.00 & 0.01 & UDL & UDL & 0.12 & 0.14 & 3.80 & UDL & UDL & UDL & UDL \\
\hline GW9 & 0.65 & UDL & UDL & UDL & UDL & 0.02 & 0.0 & 1.13 & UDL & 0.0 & UDL & 0.0 \\
\hline WHO 2004 & $0.3-1.0$ & 2.00 & 3.00 & 0.07 & 0.02 & 0.05 & 0.05 & 0.40 & 0.01 & 0.003 & 0.001 & 0.01 \\
\hline
\end{tabular}

[Note: BD- Bangladesh; GW- Ground water; SW- Surface Water; UDL-Under Detection Level; NRG- No Recommended Guideline; WHO- World Health Organization]

Mn naturally originates as a mineral from sediment and rocks or from mining activities and industrial waste [15]. The concentration of the $\mathrm{Mn}$ in the study area ranged from 0.15 $3.85 \mathrm{mg} / \mathrm{L}$ in which maximum sampling location $(82 \%)$ i.e. GW2 $\quad(3.85)>$ GW $\quad(3.80)>$ GW $1 \quad(2.65)>$ GW4 $\quad(1.26)>$ SW 1

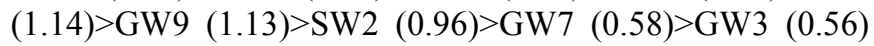
were recorded more than WHO permissible limit of $0.4 \mathrm{mg} / \mathrm{L}$ (for $\mathrm{Mn}$ ). Besides this, GW2 (3.85) $>\mathrm{GW} 8$ (3.80) $>\mathrm{GW} 1$ (2.65) $>$ GW4 (1.26) $>$ SW1 (1.14) $>$ GW9 (1.13) were also exceeded maximum BD permissible limit of $1.0 \mathrm{mg} / \mathrm{L}$ (Table
2). So, high Mn levels can have adverse effect on aquatic life, water quality by expressing some symptoms like weakness, tremors, a masklike face and psychological disturbance [16]. Besides these, the potential health effects to long-term exposure above the maximum allowable limit (unless specified as short-term) are fatness, glucose intolerance, blood clotting, skin problems, lowered cholesterol levels, skeleton disorders, birth defects, changes of hair color, neurological symptoms $[17,18]$. The most of samples of both water types are highly contaminated by $\mathrm{Mn}$ (Figure 2A).

Table 3. Concentration $(\mathrm{mg} / \mathrm{kg}$ ) of heavy metals in coal dust, soil with their permissible guidelines.

\begin{tabular}{|c|c|c|c|c|c|c|c|c|c|c|c|c|}
\hline Sample ID & $\mathbf{F e}$ & $\mathbf{C u}$ & Zn & Mo & $\mathbf{N i}$ & Co & $\mathrm{Cr}$ & Mn & $\mathbf{P b}$ & Cd & $\mathbf{H g}$ & As \\
\hline $\mathrm{CD}$ & 88.05 & 5.51 & 8.43 & UDL & 5.68 & 22.09 & 67.15 & 132.42 & 0.0 & 0.0 & 0.0 & 1.39 \\
\hline SS1 & 124.0 & 13.34 & 34.90 & UDL & 19.94 & 137.25 & 139.02 & 364.55 & 6.98 & 0.24 & 24.28 & UDL \\
\hline SS2 & 211.9 & 14.78 & 31.3 & UDL & 16.74 & 193.21 & 188.01 & 245.76 & 9.25 & 0.00 & 18.4 & 2.41 \\
\hline SS3 & 6.24 & 22.79 & 50.7 & UDL & 25.2 & 245.25 & 243.38 & 1966.52 & 16.03 & 0.00 & 0.0 & 6.58 \\
\hline FAO and EA standard & 50000 & 100 & 300 & 75 & 50 & 50 & 100 & 2000 & 100 & 3.0 & 1.0 & 20 \\
\hline
\end{tabular}

[Note: BD- Bangladesh; CD-Coal Dust; EA- Environment Agency; FAO- Food and Agricultural Organization; SS-Surface Soil; UDL-Under Detection Level]

It was supported by the study of Howladar et al. (2014) [1] which obtained $\mathrm{Fe}$ as a range from 0.75 to $1.50 \mathrm{mg} / \mathrm{L}$ by analyzing about 50 samples of surface and ground water in and around $\mathrm{BCM}$ area and was contaminated by $\mathrm{Fe}$ as the maximum acceptable limit of WHO (1997) was $0.30 \mathrm{mg} / \mathrm{L}$ [1]. But in this study, the concentration of $\mathrm{Fe}$ ranges from 0.00 to $1.88 \mathrm{mg} / \mathrm{L}$ in which GW9 (0.65)> GW8 (0.59) exceeded the WHO standard and GW2 (1.88)>GW1 (1.84) exceeded both of WHO and BD maximum permissible limit of $1.0 \mathrm{mg} / \mathrm{L}$ which indicated the occurrence of contamination of some ground water samples by Fe (Figure 2A). This higher concentration of $\mathrm{Fe}$ in water is associated with imparting brownish to laundered clothing and causes staining of bathroom fittings and encrusting in water modes [1, 19].
$\mathrm{Ni}$ has been considered to be an essential trace element for human and animal health. The maximum permissible limit of $\mathrm{WHO}$ for $\mathrm{Ni}$ in water is $0.02 \mathrm{mg} / \mathrm{L}$ [WHO 2004]. Concentration of $\mathrm{Ni}$ in water samples ranged from 0.00 to $0.087 \mathrm{mg} / \mathrm{L}$ in which $36 \%$ of samples (SW1 $>$ GW $1>$ SW2 $>$ GW2) exceeded the WHO permissible limit (Figure 2A). As the $\mathrm{BD}$ permissible value for $\mathrm{Ni}$ is $0.1 \mathrm{mg} / \mathrm{L}$, it is not a severe contamination for Bangladesh and can be used for an irrigation purpose as it does not cross the limit of $1.4 \mathrm{mg} / \mathrm{L}$ [22]. But, drainage water contains high concentration of $\mathrm{Ni}$ that may result to contamination of ground water in recent future. High quantities $\mathrm{Ni}$ can also cause cancer, respiratory failure, birth defects, allergies, dermatitis, eczema, nervous system or heart failure [19]. 


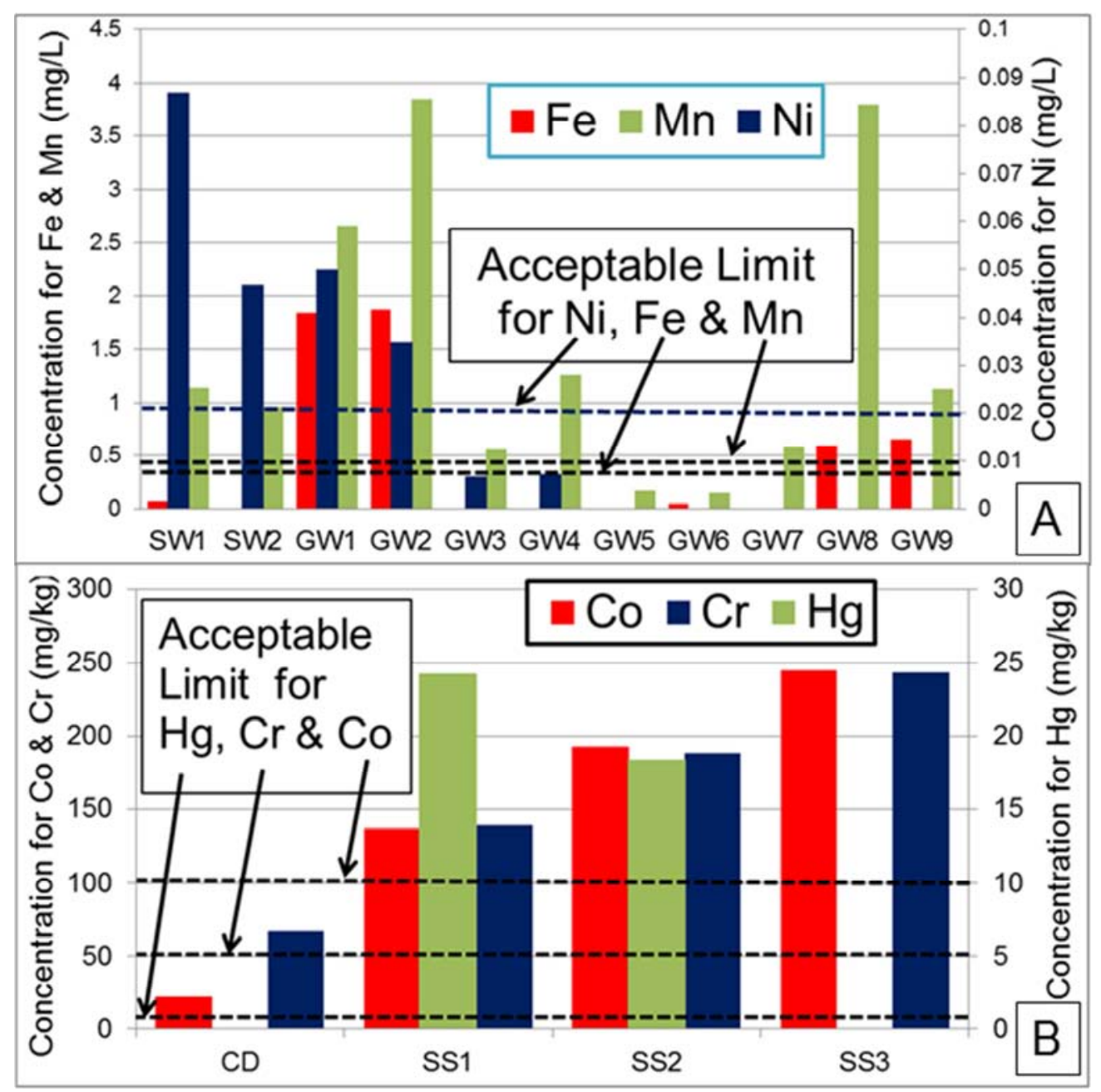

Figure 2. Concentration ( $\mathrm{mg} / \mathrm{L})$ of $\mathrm{Fe} e^{\text {total }}$, Ni and Mn in water (A); concentration ( $\left.\mathrm{mg} / \mathrm{kg}\right)$ of $\mathrm{Co}, \mathrm{Cr}$ and $\mathrm{Hg}$ in coal dust and soil (B) showing the acceptable value line. (Note: CD-Coal Dust; GW-Ground water; SS-Surface Soil; SW-Surface Water).

\subsection{Heavy Metals in Soil and Coal Dust}

The concentration level ranged from 13.34 to $22.79 \mathrm{mg} / \mathrm{kg}$ of $\mathrm{Cu}, 31.28$ to $50.71 \mathrm{mg} / \mathrm{kg}$ of $\mathrm{Zn}, 6.98$ to $16.03 \mathrm{mg} / \mathrm{kg}$ of $\mathrm{Pb}$, 0.00 to $0.24 \mathrm{mg} / \mathrm{kg}$ of $\mathrm{Cd}$ and 0.00 to $6.58 \mathrm{mg} / \mathrm{kg}$ of As while Mo was not detected in soils. The FAO permissible limit of $\mathrm{Cu}$ is $100 \mathrm{mg} / \mathrm{kg}, \mathrm{Zn}$ is $300 \mathrm{mg} / \mathrm{kg}$, Mo is $75 \mathrm{mg} / \mathrm{kg}, \mathrm{Pb}$ is $100 \mathrm{mg} / \mathrm{kg}, \mathrm{Cd}$ is $3 \mathrm{mg} / \mathrm{kg}$ and As is $20 \mathrm{mg} / \mathrm{kg}$ [20]. Therefore, the concentration of these elements in soil does not exceed the FAO permissible limit which indicated that no contamination was detected in soils by these metals. But in some cases, it is said that the maximum allowable concentration limit for $\mathrm{Mn}$ is $630-636 \mathrm{mg} / \mathrm{kg}$. Considering with this level, it may be revealed that the soil is contaminated by $\mathrm{Mn}$ and this level is high enough for absorption of Mn by plant and vegetation.

$\mathrm{Cr}$ enters environment from old mining operations runoff and leached into groundwater, fossil-fuel combustion, cement-plant emissions, mineral leaching, and waste incineration [18]. The concentration of the $\mathrm{Cr}$ was in the soil of the study area ranging from $139.02-243.38 \mathrm{mg} / \mathrm{kg}$ which was more than the maximum acceptable limit of Food and
Agricultural Organization (FAO, 1992) of $100 \mathrm{mg} / \mathrm{kg}$. Consequently, the soils of BCM and BCPP area are highly contaminated by $\mathrm{Cr}$. Therefore, the plants, animals as well as human beings are in danger because $\mathrm{Cr}$ contamination may lead to skin rashes, stomach ulcers, respiratory problems, weakened immune systems, kidney or liver damage, alteration of genetic material, lung cancer and ultimately death $[17,18,21]$.

Co also contained at a very high concentration level in soil of the study area as like as $\mathrm{Cr}$ ranging from $137.25 \mathrm{mg} / \mathrm{kg}$ to $245.25 \mathrm{mg} / \mathrm{kg}$ while the maximum acceptable limit set by the Food and Agricultural Organization (FAO, 1992) is $50 \mathrm{mg} / \mathrm{kg}$. The toxic effects on plant are unlikely to occur below soil Co concentrations of $40 \mathrm{mg} / \mathrm{kg}$ and plant species vary in their sensitivity to Co, and soil type and soil chemistry greatly influence Co toxicity [21]. One of the most important soil properties is soil acidity. It is investigated that the more acidic soils which contain Co at any concentration are greater potential for Co toxicity [20]. However, the soils of the study area are highly contaminated by Co and the plant, animals as well as human beings are at risk under the Co contamination.

The concentration level of $\mathrm{Hg}$ in all soil samples were 
recorded from $0.00 \mathrm{mg} / \mathrm{kg}$ to $24.28 \mathrm{mg} / \mathrm{kg}$ which is much higher (especially at SS1 and SS2) than EA guideline of $1.0 \mathrm{mg} / \mathrm{kg}$. The United Kingdom (UK) Soil and Herbage Survey (SHS) is a comprehensive survey of the concentrations of major contaminants in soils and herbage across the UK and SHS was found total mercury concentrations in the range 0.07 to $1.2 \mathrm{mg} / \mathrm{kg}$ for rural soils [12]. As the soils of BCM area are mainly rural, the soil is highly contaminated by $\mathrm{Hg}$. Inorganic mercury may occur in three different valent states in soil depending on factors including redox potential, $\mathrm{pH}$, soil organic matter (SOM) content and chloride ion concentration and elemental mercury $\left(\mathrm{Hg}^{0}\right)$ is stable in the presence of sulfide species under strongly reduced conditions, but at increasing redox potential, it will precipitate as mercury sulfide and it is also formed by microbial transformation from $\mathrm{Hg}$ (II) and, due to its volatility, is an important component in the cycling of mercury between soil and air [12].

The concentration levels of all heavy metals in coal dust did not exceed the recommended level.

Considering the presented results we hope to encourage health authorities to take further research steps toward epidemiological investigations and obtain detailed information on the human exposure to heavy metals and other trace elements.

\section{Conclusion}

The presence of high concentrations of $\mathrm{Mn}, \mathrm{Fe}^{\text {total }}$ and $\mathrm{Ni}$ i.e., $82 \%, 36 \%$ and $36 \%$ respectively of the studied samples above the WHO, 2004 drinking water guidelines values that are large enough to be considered a public health concern. Thereafter, the concentrations of $\mathrm{Co}, \mathrm{Cr}$ and $\mathrm{Hg}$ in the surficial soils were higher than the safe values which indicate that the soils around BCM area has been contaminated at a moderate to higher polluted level. This study suggested that point sources of heavy metals in the water and soils should be closely monitored; improvement of conditions and industrial (of BCM and BCPP) effluent and waste discharge should be reduced.

\section{References}

[1] Howladar M. F., Deb P. K., Muzemder A. T. M. S. H. \& Ahmed M. (2014). Evaluation of water resources around Barapukuria coal mine industrial area, Dinajpur, Bangladesh. Appl Water Sci 4: DOI 10.1007/s13201-014-0207-5., 203222p.

[2] Halim M. A., Majumder R. K., Zaman M. N., Hossain S., Rasul M. G. \& Sasaki K. (2012). Mobility and impact of trace metals in Barapukuria coal mining area, Northwest Bangladesh., Spinger., Arab J Geosci DOI 10.1007/s12517012-0769-1., 13pp.

[3] Seddique A. A. and Matin K. A. (2013). Assessment of groundwater vulnerability in and around Narayanganj town, Bangladesh: Insight into groundwater contamination. International Journal of Environment, Vol. 3 (1), 10-18pp.
[4] Kiran D. L., Krishna D. L., Vivek S. M., and Dilip S. R. (2012). Assessment of Heavy Metal Contaminated Soil Near Coal Mining Area in Gujarat By Toxicity Characteristics Leaching Procedure, Int. J. LifeSc. Bt \& Pharm. Res. 2012, 73-80pp.

[5] Earth Summit (1992). Programme of action for sustainable development (174-175). Agenda 21, UNCED, Rio deJaneiro, Brazil.

[6] WHO (1984). International standards for drinking water. Geneva: World Health Organization.

[7] Wardell A (1991). Techno-economic feasibility study, Barapukuria coal project, Dinajpur district, Bangladesh. vol 1, 2.

[8] Bakr M. A., Rahman Q. M. A., Islam M. M., Islam M. K., Uddin M. N., Resan S. A., Haider M. J., Islam M. S., Ali M. W., Choudhury M. E. A., Mannan K. M., and Anam A. N. M. H.,(1996). Geology and Coal Deposits of Barapukuria Basin, Dinajpur District, Bangladesh. Records of Geological Survey of Bangladesh, Vol. 8, Part. 1, pp. 36.

[9] Senapaty A. and Behera P. (2012). Concentration and Distribution of Trace Elements in Different Coal Seams of the Talcher Coalfield, Odisha., International Journal of Earth Science and Engineering., ISSN 0974-5904, Volume 05, No. 01., Pp. 80-87.

[10] APHA, (1995). Standard methods for the examination of water and waste water 19th edition. American Public Health Association and Water Pollution Control Federation, Washington D. C.

[11] Food And Agriculture Organization (FAO, 1992). Wastewater treatment and use in agriculture -FAO irrigation and drainage paper 47, by M. B. sescod.

[12] EAR (Environmental Agency Report) (2009). Published by: Environment Agency, Rio House, Waterside Drive, Aztec West, Almondsbury, Bristol. BS32 4UD., at https://www.gov.uk/government/uploads/system/uploads/attac hment data/file/313877/scho0309bpqg-e-e.pdf. Accessed July 15,2015 .

[13] BNDWQS (Bangladesh National Drinking Water Quality Survey) (2009). Bangladesh Bureau of Statistics, Planning Division, Ministry of Planning, Government of the People's Republic of Bangladesh., by Unicef Bangladesh., Published at 22, March 2011., 196p. Available at http://www.bbs.gov.bd. Accessed July 20, 2015.

[14] National Research Council (US) Safe Drinking Water Committee (1977). Drinking Water and Health: Volume 5. Washington (DC): Amendment to the Safe Drinking Water Act.

[15] Reddy T. B., Ramana Ch. V., Bhaskar Ch. \& Chandrababu P. J. (2012). Assessment Of Heavy Metal Study On Ground Water In And Around Kapuluppada Msw Site, Visakhapatnam, AP., I. J. S. N., VOL. 3 (2) 2012: 468-471, ISSN $2229-6441,468-471 \mathrm{p}$.

[16] Calkins M. (2009). Materials for sustainable sites: A complete guide to the evaluation. Hoboken, New Jersey: John Wiley and Sons. pp. 451.

[17] EPA. (2004). Drinking water health advisory for Mn. Accessed from http://www.epa.gov/safewater. Accessed July 13, 2015. 
[18] WHO (2004). Guideline for Drinking Water Quality World Health Organization, Geneva., ISBN: 924154638 7., Vol. 1: $3^{\text {rd }}$ ed. 515 pp.

[19] Marfo B. T, (2014). Heavy Metals Contaminations Of Soil And Water At Agbogbloshie Scrap Market, Accra., St, Id: Pg 4171010; A Thesis Submitted To The Department Of Theoretical And Applied Biology, Kwame Nkrumah University Of Science And Technology., Master Of Science Degree In Environmental Science. 71pp.

[20] Chiroma T. M., Ebewele R. O. And Hymore F. K. (2014). Comparative Assessement Of Heavy Metal Levels In Soil, Vegetables And Urban Grey Waste Water Used For Irrigation In Yola And Kano., International Refereed Journal of Engineering and Science (IRJES)., ISSN (Online) 2319-183X, (Print) 2319-1821., Volume 3, Issue 2 (February 2014), Pp. 01-09.

[21] Khan M. A., Ajid A. W., Noor S., Khaitak F. K., Akhter S. And Rahman I. Ur. (2008). Effect of Soil Contamination on Some Heavy Metals Content of Cannabis sativa., J. Chem. Soc. Pak., Vol. 30, No. 6, 2008, 805-809pp.

[22] Sarker S. K., Baten M. A., Haque M. E., Hossain M. S. and Rahman S. M. M., (2010). Effect of Barapukuria coal mine on soil environment, J. Agrofor. Environ. 4 (2): ISSN 19956983., 181-183pp.
[23] Farhaduzzaman M., Abdullah, WH. and Islam, MA. (2012). Depositional environment and hydrocarbon source potential of the Permian Gondwana coals from the Barapukuria basin, Northwest Bangladesh. International Journal of Coal Geology, Vol. 90-91 No. 1, pp. 162-179.

[24] Hildebrand R. T. (2011). Challenges of Coalbed Natural Gas Development in Northwestern Bangladesh., Search and Discovery Article \#80134 (2011). Posted February 21, 2011. Adapted from oral presentation at AAPG International Conference and Exhibition, Calgary, Alberta, 23pp.

[25] Khan A. A., Chouhan R. K. S. (1996). The crustal dynamics and the tectonic trends in the Bengal basin. J Geodyn 22: 267286pp.

[26] Alam M., Alam M. M., Curray J., Chowdhury R. M. L. R., Gani M. R. (2003). An overview of the sedimentary geology of the Bengal basin in relation to the regional tectonic framework and basin-fifill history. Sediment Geol 155: 179208pp.

[27] Department of Environment, Government of the People's Republic of Bangladesh, 1997. ECR (The Environment Conservation Rules). Poribesh Bhaban E-16, Agargaon, Shere Bangla Nagar Dhaka 1207, Bangladesh pp. 179-226. 